\title{
FAKTOR-FAKTOR YANG MEMPENGARUHI KEPUTUSAN PETANI MENANAM JAGUNG MANIS DAN JAGUNG LOKAL
}

\author{
David Harksel Andre Ratulangi \\ Theodora Maulina Katiandagho \\ Benny Adrian Berthy Sagay
}

\begin{tabular}{ll}
\hline Naskah diterima melalui Website Jurnal Ilmiah agrisosioekonomi@unsrat.ac.id & : Jumat, 11 Oktober 2019 \\
Disetujui diterbitkan & $:$ Kamis, 24 Oktober 2019 \\
\hline
\end{tabular}

\begin{abstract}
This study aims to determine the factors that influence farmers' decisions in planting sweet corn and local corn in Tolombukan Satu Village, Pasan District, Southeast Minahasa Regency. Data collection was carried out for two months, from May to June 2019. The collected data was compiled quantitatively and displayed in tabular form. This research uses primary data and secondary data. Primary data obtained from interviews and with the help of questionnaires for the leader (chair, secretary, and treasurer) and all members of the Nafiri Jaya Farmer Group amounted to 20 people. Secondary data obtained from local book store, the internet through Google Scholar to get articles and theses from other universities related to research topics on factors that influence farmers' decisions. The results showed that the factors influencing the decision of farmers to plant sweet corn and local corn were social factors and economic factors. Social factors consist of age, level of education, experience in farming and the role of agricultural extension workers. Economic factors consist of the number of dependents in the family, land area, facilities and infrastructure, income, expenses and selling price. ${ }^{*}$ prm ${ }^{*}$
\end{abstract}

Keywords: corn farmers, sweet corn, local corn, decision

\begin{abstract}
ABSTRAK
Penelitian ini bertujuan untuk mengetahui faktor-faktor yang mempengaruhi keputusan petani dalam menanam jagung manis dan jagung lokal di Desa Tolombukan Satu Kecamatan Pasan Kabupaten Minahasa Tenggara. Pengumpulan data dilakukan selama dua bulan yaitu dari bulan Mei sampai dengan Juni 2019. Data yang terkumpul disusun secara kuantitatif yang ditampilkan dalam bentuk tabel. Penelitian ini menggunakan data primer dan data sekunder. Data primer yang diperoleh dari wawancara dan dengan bantuan kuesioner terhadap pengurus (Ketua, Sekretaris, dan Bendahara) dan seluruh anggota Kelompok Tani Nafiri Jaya berjumlah 20 orang. Data sekunder yang diperoleh dari tokoh buku lokal, internet melalui google cendekia untuk mendapatkan artikel dan skripsi dari perguruan tinggi lain yang berkaitan dengan topik penelitian tentang faktor-faktor yang mempengaruhi keputusan petani. Hasil penelitian menunjukkan bahwa faktor-faktor yang mempengaruhi keputusan petani menanam jagung manis dan jagung lokal yaitu faktor sosial dan faktor ekonomi. Faktor sosial terdiri atas umur, tingkat pendidikan, pengalaman berusaha tani jagung dan peran penyuluh pertanian. Faktor ekonomi terdiri atas jumlah tanggungan dalam keluarga, luas lahan, sarana dan prasarana, pendapatan, pengeluaran dan harga jual. ${ }^{* e p r m *}$
\end{abstract}

Kata kunci: petani jagung, jagung manis, jagung lokal, keputusan 


\section{PENDAHULUAN}

\section{Latar Belakang}

Jagung merupakan komoditas penting kedua setelah padi/beras di Indonesia. Kebutuhan jagung dari tahun ke tahun terus meningkat seiring dengan terus bertambahnya jumlah penduduk. Dari data Ditjen Tanaman Pangan mengenai sasaran produksi nasional 2018 sebesar 33,9 juta ton, kebutuhan jagung untuk industri pakan sebesar $32 \%$ dari total produksi sedangkan untuk kebutuhan pangan sebesar $14 \%$ dari total produksi. Selain untuk pakan ternak, jagung juga memiliki potensi yang besar di bidang industri pangan sebagai bahan baku industri makanan dan minuman. Contohnya untuk bahan baku indsutri Cemilan (marning jagung dan popcorn), tepung jagung (maizena), Corn Grits (bubur jagung), Sweetener, Susu Jagung dan sebagainya.

Kebutuhan jagung untuk industri sebesar 30.000.000 ton dengan rincian sebagai berikut : (1) Industri Pakan sebesar 8.300.000 ton, (2) Industri Pati Jagung dan Sweetener sebesar 760.000 ton, (3) Industri Corn Grits dan Tepung Jagung sebesar 3.000.000 ton dan (4) Industri Snack sebesar 1.000.000 ton. Kebutuhan jagung untuk industri pangan di tahun 2018 mengalami peningkatan yang cukup pesat dibandingkan tahun 2017. Industri pati jagung dan sweetener meningkat 8,57\% dibanding sebelumnya sedangkan Corn Grits dan tepung jagung serta industri Snack yang di tahun sebelumnya belum ada tapi di tahun 2018 mampu menyerap 4.000.000 ton jagung, hal ini mengindikasikan urgensinya jagung dalam memenuhi kebutuhan pangan (Kementerian Perindustrian, 2018).

Kondisi ini membuat budidaya jagung memiliki prospek yang sangat menjanjikan, baik dari segi permintaan maupun harga jualnya. Jagung sebagai salah satu tanaman pangan yang menjadi unggulan dan sangat digemari oleh masyarakat, karena rasanya yang enak, banyak mengandung karbohidrat dan sedikit protein serta lemak. Desa Tolombukan Satu merupakan salah satu desa yang ada di Kecamatan Pasan Kabupaten Minahasa Tenggara Provinsi Sulawesi Utara, yang menumpukan pembangunan ekonomi pada sektor pertanian, terutama pada sub sektor tanaman pangan berupa jagung, yang diusahakan oleh Kelompok Tani Nafiri Jaya sejak tahun 2009.

Usahatani jagung menjadi pilihan dari para petani yang tergabung dalam kelompok tani tersebut. Jagung yang ditanam oleh petani di Desa Tolombukan Satu adalah jenis Jagung Manis dan Jagung Lokal, karena dianggap sebagai komoditas yang berpotensi dan cocok dengan kondisi alam yang ada serta berpeluang memberikan untung yang tinggi bila diusahakan secara efektif dan efisien. Maka, berdasarkan uraian tersebut, dirasa perlu dilakukan analisis mengenai faktor-faktor yang mempengaruhi keputusan petani dalam menanam jagung manis dan jagung lokal di Desa Tolombukan Satu.

Berdasarkan latar belakang yang dikemukakan, maka yang menjadi permasalahan dalam penelitian ini adalah faktor-faktor apakah yang mempengaruhi keputusan petani dalam menanam jagung manis dan jagung lokal di Desa Tolombukan Satu Kecamatan Pasan Kabupaten Minahasa Tenggara?

\section{Karakteristik Petani}

Menurut Mathew and Zajac dalam Zaenudin (2012), menyatakan bahwa karakteristik personal (individu) mencakup usia, jenis kelamin, masa kerja, tingkat pendidikan, suku bangsa dan kepribadian. Karakteristik individu adalah bagian dari pribadi dan melekat pada diri seseorang. Karakteristik ini mendasari tingkah laku seseorang dalam situasi kerja maupun situasi yang lainnya.

\section{Deskripsi Tanaman Jagung}

Tanaman jagung dikenal di Indonesia sejak 400 tahun yang lalu, didatangkan oleh orang Portugis dan Spanyol. Daerah sentra produsen jagung paling luas adalah provinsi Jawa Timur, Jawa Tengah, Sulawesi Selatan, Nusa Tenggara Timur, Lampung dan Jawa Barat. Areal pertanaman jagung sekarang sudah terdapat di seluruh provinsi di Indonesia. Tanaman jagung termasuk jenis tanaman semusim (annual). Susunan tubuh (morfologi) tanaman jagung terdiri atas akar, batang, batang daun, bunga dan buah. Perakaran tanaman jagung terdiri atas empat macam akar, akar utama, akar cabang, akar lateral dan akar rambut (Rukmana, 2008).

Menurut Purwono dan Hartono (2007) secara umum klasifikasi dan sistematika tanaman jagung sebagai berikut :

$\begin{array}{ll}\text { - Kingdom } & \text { : Plantae (Tumbuh- } \\ \text { - Divisi } & \text { : Spermatophyta } \\ \text { - Subdivisi } & \text { : Angiospermae } \\ \text { - Kelas } & \text { : Monocotyledone } \\ \text { - Ordo } & \text { : Graminae } \\ \text { - Famili } & : \text { Graminaceae } \\ \text { - Genus } & : \text { Zea } \\ \text { - Species } & \text { :Zea mays L }\end{array}$




\section{Jagung Manis}

Jagung manis (sweet corn) merupakan komoditas palawija dan termasuk dalam keluarga (famili) rumput-rumputan (Gramineae)genus Zea dan spesies Zea mays saccharata. Jagung manis memiliki ciri-ciri endosperm berwarna bening, kulit biji tipis, kandungan pati sedikit, pada waktu masak biji berkerut Koswara, (2009).

Hampir semua bagian dari tanaman jagung manis memiliki nilai ekonomis. Beberapa bagian tanaman yang dapat dimanfaatkan diantaranya, batang dan daun muda untuk pakan ternak, batang dan daun tua (setelah panen) untuk pupuk hijau / kompos, batang dan daun kering sebagai kayu bakar, buah jagung muda untuk sayuran, perkedel, bakwan dan berbagai macam olahan makanan lainnya Purwono dan Hartono, (2007).

Menurut Syukur dan Rifianto (2014), jagung manis memiliki karakteristik unggul sebagai berikut :

1) Produktivitas Tinggi

Potensi produktivitas jagung manis hibrida tanpa kelobot dapat mencapai 20 ton/ha/musim tanam. Potensi harus ditunjang oleh kualitas buah yang baik, seperti ukuran, penampilan, biji, dan rasa.

2) Rasa Manis

Selain produktivitas, sifat utama jagung manis yang dikembangkan adalah rasa manis. Konsumen jagung manis menginginkan rasa manis yang tinggi dan tetap manis setelah disimpan beberapa hari.

3) Umur Panen Genjah

Umumnya umur panen jagung manis adalah 70-85 HST di dataran menengah dan 60-70 HST di dataran rendah.

4) Daya Simpan Lebih Lama

Jagung manis biasanya langsung dijual setelah panen, karena mutu akan turun setelah 2-3 hari disimpan dalam suhu kamar. Jagung manis unggul mempunyai daya simpan lebih tinggi dan rasa manis tidak cepat turun selama penyimpanan. Jagung manis umumnya dipanen kira-kira 18-24 hari setelah penyerbukan, dan biasanya ditandai dengan penampakan luar rambut yang mngering, tongkol yang keras ketika digenggam.

\section{Jagung Lokal (Jagung Manado Kuning)}

Jagung Manado Kuning adalah jenis jagung bersari bebas, keluar rambut 60 hari, umur panen 105 - 110 hari, warna biji kuning, tidak tahan bulai (Sclerospora maydis), dan sudah dilepas sebelum tahun 1945. Dinamakan jagung bersari bebas (open pollinated crop) karena hampir $95 \%$ persarian jagung berasal dari serbuk sari tanaman lain, dan hanya $5 \%$ yang berasal dari serbuk sari sendiri. Tipe jagung Manado Kuning digolongkan pada tipe flint atau mutiara.Biji jagung tipe flint atau mutiara berbentuk bulat licin, mengkilap, dan keras.Bagian pati yang keras terdapat di bagian atas biji, pada saat masak bagian atas biji mengkerut bersama-sama sehingga permukaan biji bagian atas licin dan bulat. Varietas lokal jagung di Indonesia umumnya tergolong ke dalam tipe biji mutiara, tipe ini disukai petani karena tahan hama gudang.

Seiring dengan berkembangnya penanaman jagung hibrida di Sulawesi Utara, jagung Manado Kuning ditanam berdekatan dengan jagung hibrida, yang bisa menyebabkan terjadi persilangan secara alami antara kedua jagung tersebut.Hal ini menyebabkan jagung Manado Kuning yang dikembangkan petani dewasa ini sudah sangat beragam satu daerah dengan daerah lainnya.Jagung Manado Kuning yang ditanam petani ada dua tipe biji, yaitu flint dan dent, dengan dua warna biji, yaitu kuning dan kuning oranye. Umumnya jagung Manado Kuning ditanam petani untuk dimanfaatkan sebagai: 1) Butir, 2) Tepung, 3) Pakan dalam bentuk jerami, dan 4) Pangan. Khusus daerah Tompaso, karena daerah ini banyak ternak kuda pacu maka hasil jagung Manado Kuning, selain dimanfaatkan dalam bentuk biji, tapi dimanfaatkan juga dalam bentuk jerami.

\section{Teori Keputusan}

Teori keputusan adalah teori mengenai cara manusia memilih pilihan diantara pilihan-pilihan yang tersedia secara acak guna mencapai tujuan yang hendak diraih (Hanson, 2005). Dalam istilah umum, keputusan adalah penyeleksian tindakan dari dua atau lebih pilihan alternatif (Schiffman dan Kanuk, 2004). Dengan kata lain, keputusan dapat dibuat hanya jika ada beberapa alternatif yang dipilih. Apabila alternatif pilihan tidak ada maka tindakan yang dilakukan tanpa adanya pilihan tersebut tidak dapat dikatakan membuat keputusan.

Pengambilan keputusan dilakukan dengan memilih alternatif yang ada (Terry,2000). Menurut Rogers (2003) pengambilan berbagai alternatif tersebut tidak terlepas dari berbagai pertimbangan menguntungkan atau tidak menguntungkan suatu teknologi bagi pengusahanya (petani).Sementara tingkat adopsi suatu inovasi tersebut dipengaruhi oleh karakteristik inovasi itu sendiri, karakteristik penerima inovasi dan saluran komunikasi.

Keputusan-keputusan yang diambil oleh seseorang dapat dipahami melalui dua pendekatan pokok, yaitu pendekatan normatif dan pendekatan deskriptif. Pendekatan normatif menekankan pada apa yang seharusnya dilakukan oleh pembuat keputusan sehingga diperoleh suatu keputusan yang rasional. Pendekatan deskriptif menekankan pada apa saja yang telah dilakukan orang yang membuat keputusan tanpa melihat apakah keputusan yang dihasilkan itu rasional atau tidak rasional (Suharnan, 2005).

Pada setiap pembuatan keputusan, seorang individu dapat bersifat terbuka maupun bersifat tertutup dalam menentukan pilihan keputusan. Seorang individu yang bersifat terbuka, 
tidak akan membatasi pilihan dan seringkali menambahkan pilihan baru diluar pilihan yang ada. Disisi lain, seorang individu yang bersifat tertutup tidak akan menambah pilihaan yang telah ada. Dalam kehidupan nyata kemungkinan pilihan terbuka lebih sering terjadi.

Berdasarkan uraian tersebut faktor-faktor yang mempengaruhi keputusan petani dalam menanam jagung manis dan jagung lokal adalah umur, adalah factor ssosial dan factor ekonomi.

\section{Faktor Sosial}

1) Umur

Umur dapat mempengaruhi aktivitas seseorang dalam bekerja.Dalam kondisi umur yang masih produktif maka kemungkinan besar seseorang dapat bekerja dengan baik dan maksimal (Hasyim, 2006). Hal tersebut terutama berlaku pada pekerjaan fisik. Semakin berat pekerjaan secara fisik maka semakin tua tenaga kerja akan semakin turun pula prestasinya(Suratiyah, 2008).

2) Tingkat Pendidikan

Menurut Muhibbin (2002) pendidikan dapat menyempurnakan perkembangan individu dalam menguasai pengetahuan, kebiasaan, sikap dan sebagainya.Tingkat pendidikan individu merupakan salah satu aspek yang terlibat dalam suatu pengambilan keputusan.

3) Pengalaman Berusahatani

Semakin lama petani bekerja pada kegiatan tersebut, maka semakin banyak pengalaman yang diperoleh dan diharapkan akan lebih menguasai serta lebih terampil dalam teknik budidaya, teknologi pasca panen dan penguasaan teknologi lainnya yang berkaitan dengan usahataninya (Soekartawi, 2003).

4) Peran Penyuluh Pertanian

Penyuluhan merupakan keterlibatan seseorang untuk melakukan komunikasi informasi secara sadar dengan tujuan membantu sesamanya memberikan pendapat sehingga bisa membuat keputusan yang benar.

\section{Faktor Ekonomi}

1) Jumlah Tanggungan

Semakin banyak anggota keluarga akan semakin besar pula beban hidup yang akan ditanggung atau harus dipenuhi dan dapat mempengaruhi keputusan seseorang dalam berusaha. Petani yang memiliki jumlah tanggungan yang besar harus mampu mengambil keputusan yang tepat agar tidak mengalami resiko yang fatal (Soekartawi, 2003).
2) Luas Lahan

Sajogyo (1999) menyatakan bahwa luas lahan merupakan salah satu faktor penting yang menentukan tingkat kesejahteraan petani.Semakin luas areal tani maka semakin tinggi produksi dan pendapatan yang diterima petani.

3) Pendapatan Petani

Sahidu (1998) menyatakan bahwa pendapatan usahatani merupakan sumber motivasi bagi petani dalam mendorong kemauan dan kemampuan untuk meningkatkan kinerja petani.

4) Sarana dan Prasarana Usahatani

Sarana adalah segala sesuatu yang dapat di pakai sebagai alat dan bahan untuk mencapai maksud dan tujuan dari suatu proses produksi contoh : sabit, cangkul, polybag dan lainlain.Prasarana adalah segala sesuatu yang merupakan penunjang utama terselenggaranya produksi. Contoh : lahan, jalan, parit, pabrik, tempat kerja dan lain-lainnya.

5) Harga Jual

Menurut Supriono (2001) Harga jual adalah jumlah moneter yang dibebankan oleh suatu unit usaha kepada pembeli atau pelanggan atas barang atau jasa yang dijual atau diserahkan.

\section{Skema Kerangka Penelitian}

Secara sederhana skema kerangka penelitian dibagi dalam Dua Faktor, yaitu Faktor Sosial dan Faktor Ekonomi. Dapat dilihat dalam gambar berikut ini :

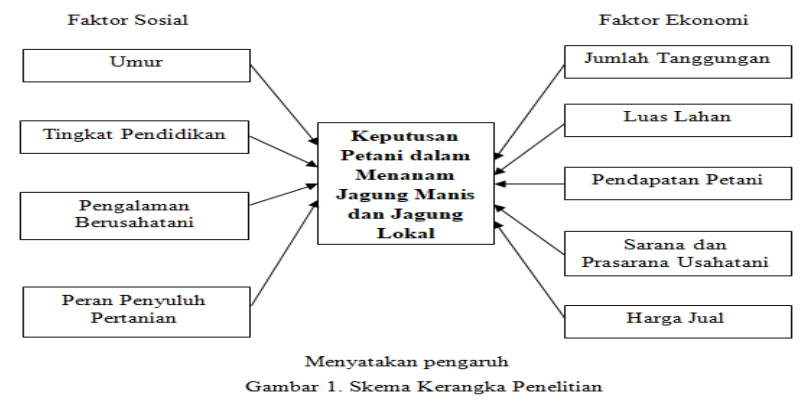

\section{Rumusan Masalah}

Berdasarkan latar belakang yang dikemukakan, maka yang menjadi permasalahan dalam penelitian ini adalah faktor-faktor apakah yang mempengaruhi keputusan petani dalam menanam jagung manis dan jagung lokal di Desa Tolombukan Satu Kecamatan Pasan Kabupaten Minahasa Tenggara? 


\section{Tujuan Penelitian}

Tujuan penelitian ini adalah untuk mengetahui faktor-faktor yang mempengaruhi keputusan petani dalam menanam jagung manis dan jagung lokal di Desa Tolombukan Satu Kecamatan Pasan Kabupaten Minahasa Tenggara.

\section{Manfaat Penelitian}

1. Sebagai bahan informasi, penelitian ini diharapkan dapat berguna bagi petani dalam rangka terus mengembangkan usahatani jagung manis dan jagung lokal di Desa Tolombukan Satu.

2. Sebagai proses belajar, bagi peneliti dapat melatih cara berpikir serta menganalisis data, dan penelitian ini merupakan salah satu syarat untuk memperoleh gelar sarjana.

3. Sebagai landasan teori, bagi peneliti lain dapat dijadikan referensi kajian dalam bidang penelitian yang serupa.

\section{Lokasi dan Waktu Penelitian}

Penelitian ini dilaksanakan selama 3 bulan dari bulan April sampai dengan bulan Juli 2019. Mulai dari persiapan sampai dengan penyusunan laporan hasil penelitian. Tempat penelitian dilaksanakan di Desa Tolombukan Satu, Kecamatan Pasan, Kabupaten Minahasa Tenggara.

\section{Jenis dan Sumber Data}

Data yang dipakai dalam penelitian ini adalah data primer dan data sekunder. Data primer data yang diambil oleh peneliti dilapangan langsung dari sumbernya yaitu Kelompok Tani Nafiri Jaya. Data ini diperoleh dari wawancara secara langsung, sedangkan data sekunder diperoleh dari instansi pemerintah atau lembaga yang terkait dengan penelitian ini seperti Kantor Desa dan Kantor Kecamatan, Serta Refrensi melalui internet.

\section{Teknik Pengumpulan Data}

Teknik pengumpulan data yang digunakan dalam penelitian ini adalah sebagai berikut :

1) Observasi

Teknik observasi adalah teknik pengumpulan data yang dilakukan dengan mengadakan pengamatan langsung terhadap objek yang akan diteliti sehingga didapatkan gambaran yang jelas mengenai objek yang akan diteliti tersebut.

2) Wawancara

Teknik wawancara merupakan teknik pengumpulan data yang dilakukan dengan cara tanya jawab tatap muka antara pewawancara dengan responden berdasarkan daftar pertanyaan (quisioner) yang telah dipersiapkan sebelumnya.

\section{Metode Pengumpulan Data}

Pengambilan data yang digunakan dalam penelitian ini adalah Sensus. Data diambil secara sengaja dan dilakukan kepada semua anggota Kelompok Tani Nafiri Jaya di Desa Tolombukan Satu Kecamatan Pasan Kabupaten Minahasa Tenggara yang pernah aktif maupun tidak aktif dalam melakukan keputusan menanam jagung manis dan jagung lokal. Jumlah anggota petani yaitu keseluruhan anggota kelompok tani/populasi sebanyak 20 orang termasuk Pengurus (Ketua, Sekretaris, dan Bendahara).

\section{Konsep Pengukuran Variabel}

Variabel-variabel yang akan diukur dalam penelitian ini adalah :

1) Umur (Tahun)

2) Tingkat Pendidikan (SD, SMP, SLA, Sarjana)

3) Pengalaman Berusahatani (Tahun)

4) Jumlah Tanggungan Keluarga (Orang)

5) Luas Lahan (ha)

6) Pendapatan Petani (Rp / Musim Tanam )

7) Sarana dan Prasarana Usahatani (Bibit, Pupuk, TK, Alat + Bahan)

8) Peran Penyuluh Pertanian

9) Harga Jual $(\mathrm{Rp} / \mathrm{Kg})$.

\section{Metode Analisis Data}

Data yang dikumpulkan dalam penelitian ini diolah dengan menggunakan metode analisis deskriptif dalam bentuk tabel.

\section{HASIL DAN PEMBAHASAN}

\section{Deskripsi Wilayah Penelitian}

\section{Keadaan Topografi}

Desa Tolombukan Satu berada pada ketinggian $300 \mathrm{~m}$ dari permukaan laut dengan suhu maximum $34^{\circ} \mathrm{C}-24^{\circ} \mathrm{C}$. Dengan rata-rata curah hujan $800 \mathrm{~mm}-1300 \mathrm{~mm}$ setiap tahun. Secara geografis Desa Tolombukan Satu merupakan salah satu desa di Kecamatan Ratahan dengan batas-batas sebagai berikut

- Utara : Hutan Lindung Gunung Soputan

- Selatan : Desa Tolombukan

- Timur : Desa Liwutung

- Barat : Desa Molompar

\section{Keadaaan Penduduk dan Tingkat Pendidikan}

Desa Tolombukan Satu memiliki jumlah penduduk yang relatif banyak, berjumlah1.028 jiwa yang terdiri dari 277 kepala keluarga(KK).

Menurut teori human capital, kualitas sumber daya manusia selain ditentukan oleh tingkat kesehatan juga ditentukan oleh tingkat pendidikan. Pendidikan dipandang tidak hanya dapat menambah pengetahuan tetapi juga dapat meningkatkan keterampilan tenaga 
kerja sehingga akan meningkatkan produktivitas. Peningkatan produktivitas dapat meningkatkan pertumbuhan ekonomi dan meningkatkan penghasilan dan kesejahteraan penduduk. Selain keterampilan, tingkat pendidikan juga mempunyai pengaruh terhadap pola pikir masyarakat (Senoaji, 2011).

Secara umum masyarakat yang tinggal di Desa Tolombukan memiliki tingkat pendidikan yang rendah.Tingkat Pendidikan masyarakat Desa Tolombukan disajikan pada Tabel 1.

Tabel 1. Tingkat Pendidikan masyarakat Desa Tolombukan

\begin{tabular}{llcc}
\hline No & $\begin{array}{l}\text { Tingkat } \\
\text { Pendidikan }\end{array}$ & $\begin{array}{c}\text { Jumlah masyarakat } \\
\text { (Orang) }\end{array}$ & Persentase (\%) \\
\hline 1 & SD & 356 & 34,64 \\
2 & SMP & 409 & 39,78 \\
3 & SMA/SMK & 230 & 22,38 \\
4 & Diploma/S1 & 30 & 2,91 \\
5 & S2 & 3 & 0,29 \\
\hline & Jumlah & 1028 & 100 \\
\hline
\end{tabular}

Sumber: Diolah dari Data Primer, 2019

Tabel 1 menunjukkan bahwa tingkat pendidikan masyarakat di Desa Tolombukanbervariasi mulai dari Sekolah Dasar (SD) dengan persentase 34,64\%, Sekolah Menengah Pertama (SMP) dengan persentase 39,78\%, Sekolah Menengah Atas (SMA) dengan persentase 22,38\% dan Diploma III (D3) / Strata 1 (S1) dengan persentase 2,91\%, serta Strata 2 / S2 $0,29 \%$.

Tabel 2. Mata Pencaharian masyarakat Desa Tolombukan

\begin{tabular}{llcr}
\hline No & Mata Pencaharian & $\begin{array}{c}\text { Jumlah masyarakat } \\
\text { (Orang) }\end{array}$ & Persentase (\%) \\
\hline 1 & Petani & 270 & 26,26 \\
2 & Pegawai Swasta & 39 & 3,80 \\
3 & Tukang & 118 & 11,48 \\
4 & PNS & 14 & 1,36 \\
5 & Pensiunan & 7 & 0,68 \\
6 & TNI/POL:RI (tidak & 2 & 0,20 \\
7 & Lain-lain & 578 & 56,22 \\
& bekerja) & 1028 & 100 \\
\hline & Jumlah
\end{tabular}

Tabel 2 menunjukkan jenis mata pencaharian penduduk di Desa Tolombukan Satu diantaranya Petani 270 orang $(26,26 \%)$, Pegawai Swasta 39 orang (3,80\%), Tukang 118 orang $(11,48 \%)$, PNS 14 orang $(1,36 \%)$, Pensiunan 7 orang $(0,68 \%)$, TNI/POLRI2 orang $(0,20 \%)$ dan lain-lain atau tidak bekerja 578 orang $(56,22 \%)$. Dari data tersebut mayoritas mata pencaharian masyarakat di Desa Tolombukan Satu adalah sebagai Petani karena banyaknya lahan perkebunan yang diambil hasil kebunnnya untuk dimanfaatkan atau dijual. Selain itu penduduk yang tidak bekerja terdiri dari anak-anak, pelajar, lanjut usia dan sebagainya.
Deskripsi Kelompok Tani Nafiri Jaya

Kelompok Tani Nafiri Jaya berdiri pada tanggal 17 Januari 2009.Kelompok tani dibentuk berdasarkan kesepakatan anggota melalui pertemuan dan mengambil keputusan untuk mengembangkan kelompok tani dengan tujuan kesejahteraan kelompok tani maupun kesejahteraan bersama.Kelompok tani Nafiri Jaya sampai saat ini bukan hanya mngandalkan komoditi jagung, tetapi juga kacang-kacangan.Jumlah anggota pada awal terbentuk adalah 20 orang keseluruhan sampai sekarang.

Rapat anggota kelompok tani hanya dilakukan setiap ada pekerjaan atau saat berada di ladang.

Sejak terbentuk kelompok Tani Nafiri Jaya, pemerintah telah memberikan bantuan awal berupa pupuk dan benih. Pada tahun 2018 tepatnya pada bulan agustus pemerintah juga memberikan bantuan berupa traktor,alat tanam jagung manual, dan cornsaler.

\section{Karakteristik Responden}

Umur

Umur dapat mempengaruhi kemampuan seseorang untuk bekerja secara fisik. Umur juga mempengaruhi produktivitas kerja dan peranannya dalam pengambilan keputusan dari berbagai alternatif pekerjaan yang dilakukan.Umur produktif antar 16 hingga 64 tahun. Karakteristik Responden Menurut Umur disajikan pada Tabel 3.

\begin{tabular}{lccr}
\multicolumn{6}{c}{ Tabel 3. Karakteristik RespondenMenurut Umur } \\
\hline No & Umur & Jumlah Responden & Persentase (\%) \\
\hline 1 & 20-30 Tahun & 1 & 5 \\
2 & $31-40$ Tahun & 5 & 25 \\
3 & 41-50 Tahun & 5 & 25 \\
4 & 51-60 Tahun & 4 & 20 \\
5 & 61-70 Tahun & 4 & 20 \\
6 & 71-80 Tahun & 1 & 5 \\
\hline \multicolumn{5}{l}{ Sumber : Diolah dari data primer 2019 }
\end{tabular}

\section{Jenis Kelamin}

Tabel 4 menunjukkan,jumlah responden menurut jenis kelamin laki-laki lebih banyak di bandingkan perempuan dengan persentase laki-laki sebanyak $55 \%$ dan responden yang berjenis kelamin perempuan menunjukkan persentase sebanyak $45 \%$.

\begin{tabular}{cccc}
\multicolumn{4}{c}{ Tabel 4. Karakteristik Responden Berdasarkan Jenis Kelamin } \\
\hline No & Jenis Kelamin & Jumlah Responden & Persentase (\%) \\
\hline 1 & laki-laki & 11 & 55 \\
2 & Perempuan & 9 & 45 \\
\hline & Jumlah & 20 & 100 \\
\hline
\end{tabular}

Sumber : Diolah dari data primer 2019

\section{Lama Usaha Tani Jagung}

Tabel 5 menunjukkan jumlah responden dengan Lama berusaha Tani Jagung, 6-10 tahun menunjukkan paling banyak dengan persentase $50 \%$, untuk lama usaha tani jagung 1-5 tahun, terdapat 9 responden dengan persentase $45 \%$, lama usaha tani jagungdi atas 11 tahun terdapat 1 responden dengan persentase $5 \%$. 
Tabel 5. Karakteristik Responden Berdasarkan Lama berusaha Tani Jagung

\begin{tabular}{cccc}
\hline No & Lama Usaha Tani Jagung & Jumlah Responden & Persentase (\%) \\
\hline 1 & 1-5 Tahun & 9 & 45 \\
2 & 6-10 Tahun & 10 & 50 \\
3 & Di atas 11 Tahun & 1 & 5 \\
\hline & Jumlah & 20 & 100 \\
\hline
\end{tabular}

Sumber : Diolah dari data primer 2019

\section{Jagung yang ditanam}

Jenis jagung yang di tanam oleh anggota kelompok Tani Nafiri Jaya ialah jagung lokal dan jagung manis.

Tabel 6. Jumlah Responden Berdasarkan Varitas Jagung Yang ditanam

\begin{tabular}{cccc}
\hline No & Varitas Jagung & Jumlah Responden & Persentase (\%) \\
\hline 1 & Jagung Lokal & 17 & 85 \\
2 & Jagung Manis & 3 & 15 \\
\hline & Jumlah & 20 & 100 \\
\hline
\end{tabular}

Sumber : Diolah dari data primer 2019

Tabel 6 menunjukkan bahwa jumlah responden yang menanam jagung lokal sebanyak 17 orang dengan persentase $85 \%$ dan jumlah responden yang menanam jagung manis sebanyak 3 orang dengan persentase $15 \%$.

\section{Status Lahan}

Tabel 7 menunjukkan, jumlah responden yang memiliki lahan sendiri atau sebagai pemilik 13 orang dengan persentase $65 \%$ sedangkan untuk responden yang meminjam pakai lahan 7 orang dengan persentase sebanyak $35 \%$.

Tabel 7. Karakteristik Responden Berdasarkan Status Lahan Anggota Kelompok Tani Nafiri Jaya

\begin{tabular}{cccc}
\multicolumn{4}{c}{ Kelompok Tani Nafiri Jaya } \\
\hline No & Status Lahan & Jumlah Responden & Persentase (\%) \\
\hline 1 & Pemilik & 13 & 65 \\
2 & Pinjam pakai lahan & 7 & 35 \\
\hline & Jumlah & 20 & 100 \\
\hline
\end{tabular}

Sumber : Diolah dari data primer 2019

\section{Faktor- Faktor Yang Mempengaruhi Keputusan Petani Menanam Jenis Jagung}

\section{Faktor Sosial}

Sosial berasal dari bahasa latin 'socius' yang artinya dari lahir, dibesarkan atau tumbuh dan berkembang di kehidupan masyarakat dengan kehidupan bersama (Salim.A, 2002). Faktor sosial yang mempengaruhi keputusan petani kelompok Tani Nafiri Jaya menanam jagung ialah sebagai berikut:

\section{Umur}

Umur dapat mempengaruhi produktivitas kerja dan peranan dalam proses pengambilan keputusan dalam berbagai pekerjaan yang dilakukan.

\begin{tabular}{cccr}
\multicolumn{2}{l}{ Tabel 8. Faktor umur } & & \\
\hline No & Umur & Jumlah Responden & Persentase $(\%)$ \\
\hline 1 & Produktif & 18 & 90 \\
2 & Non Produktif & 2 & 10 \\
\hline \multicolumn{7}{l}{ Sumber $:$ Diolah dari data primer 2019} & 20 & 100 \\
\end{tabular}

Tabel 8 menunjukkan bahwa umur anggota kelompok tani terbanyak ialah umur produktif sebanyak 18 orang dengan persentase $90 \%$ dan anggota kelompok tani umur non produktif sebanyak 2 orang dengan persentase $10 \%$.

\section{Tingkat Pendidikan Responden}

Pendidikan sangat berperan penting dalam menciptakan perubahan dalam masyarakat. Pendidikan juga dapat memberikan pemahaman akan baik dan buruk,garis pemisah antara sesuatu yang boleh dan tidak boleh dilakukan. Pendidikan disajikansebagai salah satu faktor yang menentukan produktifitas kerja , sikap serta kemampuan seseorang dalam berpikir dan bertindak.

\begin{tabular}{cccr}
\multicolumn{4}{c}{ Tabel 9. Faktor Pendidikan } \\
\hline \multirow{2}{*}{ No } & $\begin{array}{c}\text { Tingkat } \\
\text { Pendidikan }\end{array}$ & Jumlah Responden & Persentase (\%) \\
\hline 1 & SD & 7 & 35 \\
2 & SMP & 7 & 35 \\
3 & SMA & 5 & 25 \\
4 & D3/S1 & 1 & 5 \\
\hline & Jumlah & 20 & 100 \\
\hline
\end{tabular}

Sumber : Diolah dari data primer 2019

Tabel 9 menunjukkan, tingkat pendidikan responden bervariasi mulai dari Sekolah Dasar (SD) sebanyak 7 orang dengan persentase $35 \%$, Sekolah Menengah Pertama (SMP)sebanyak 7 orang dengan persentase 35\%, Sekolah Menengah Atas (SMA) sebanyak 5 orang dengan persentase $25 \%$ dan Diploma III (D3) 1 orang dengan persentase 5\%.

\section{Pengalaman Berusaha Tani Jagung}

Pengalaman adalah guru besar dalam hidup. Sebuah kesuksesan dan kegagalan di nilai dari seberapa berpengalamannya seseorang. Pengalaman juga di butuhkan dalam proses pertanian, khususnya dalam penanaman jagung lokal dan jagung manis.

Tabel 10. Pengalaman Berusaha Tani Jagung

\begin{tabular}{cccr}
\hline No & Pengalaman & $\begin{array}{c}\text { Jumlah } \\
\text { Responden }\end{array}$ & Persentase (\%) \\
\hline 1 & Belum & 0 & 0 \\
2 & Berpengalaman & 20 & 100 \\
\hline & Jumlah & 20 & 100 \\
\hline
\end{tabular}

Tabel 10 menunjukkan bahwa pengalaman berusaha tani jagung anggota kelompok Nafiri Jaya mempunyai pengalaman berusaha tani jagung dengan persentase $100 \%$.

\section{Peran Penyuluh Pertanian}

Peran Penyuluh Pertanian sangat penting untuk kelancaran proses pertanian. Informasi mengenai pertanian seperti benih, pupuk, alat pertanian serta teknik pertanian di butuhkan oleh para petani. 
Berdasarkan wawancara dengan seluruh anggota kelompok Tani Nafiri Jaya, semuanya pernah mengikuti penyuluhan pertanian yang di lakukan oleh penyuluh khususnya penyuluhan tentang penanaman jagung manis dan jagung lokal.

\section{Faktor Ekonomi}

Ekonomi merupakan salah satu ilmu sosial yang mempelajari aktivitas sosial manusia yang berhubungan dengan produksi,distribusi dan konsumsi terhadap barang dan jasa. Faktor ekonomi yang mempengaruhi petani kelompok Tani Nafiri Jaya dalam menanam jagung ialah jumlah tanggungan dalam keluarga, luas lahan, pendapatan petani jagung, sarana dan pra-sarana, dan harga jual.

\section{Jumlah Tanggungan Dalam Keluarga}

Tabel 11 menunjukkan jumlah tanggungan keluarga anggota kelompok tani Nafiri Jaya, anggota yang tidak mempunyai tanggungan 1 orangdengan persentase 5\%, yangmempunyai tanggungan 1-2 orang sebanyak 7 orang dengan persentase $35 \%$ dan yang mempunyai tanggungan 3 orang keatas sebanyak 12 orang dengan persentase $60 \%$.

\begin{tabular}{cccc}
\multicolumn{2}{c}{ Tabel 11. Jumlah Tanggungan Dalam Keluarga } \\
\hline \multirow{2}{*}{ No } & $\begin{array}{c}\text { Jumlah } \\
\text { Tanggungan }\end{array}$ & $\begin{array}{c}\text { Jumlah } \\
\text { Responden }\end{array}$ & $\begin{array}{c}\text { Persentase }(\% \\
\text { ) }\end{array}$ \\
\hline \multirow{2}{*}{1} & Tidak ada & 1 & 5 \\
2 & Tanggungan & 7 & 35 \\
3 & 1-2 Orang & 12 & 60 \\
\hline & 3 Orang Keatas & 20 & 100 \\
\hline
\end{tabular}

Sumber : Diolah dari data primer 2019

\section{Luas Lahan}

Luas lahan pertanian menjadi salah satu faktor mempengaruhi keberhasilan petani dalam menanam jagung lokal dan jagung manis. Semakin besar lahan, semakin banyak jagung yang bisa di panen.

\begin{tabular}{cccr}
\multicolumn{2}{l}{ Tabel 12. Luas Lahan } & & \\
\hline \multirow{2}{*}{ No } & \multirow{2}{*}{ Luas Lahan } & $\begin{array}{c}\text { Jumlah } \\
\text { Responden }\end{array}$ & $\begin{array}{r}\text { Persentase } \\
(\%)\end{array}$ \\
& & 11 & 55 \\
1 & Lebih Kecil < 1ha & 9 & 45 \\
\hline & Lebih Besar $>1$ ha & 20 & 100 \\
\hline
\end{tabular}

Sumber : Diolah dari data primer 2019

Tabel 12 menunjukkan bahwa, luas lahan yang digunakan oleh anggota kelompok Nafiri Jaya mempunyai luas lahan lebih kecil < 1ha sebanyak 11 orang dengan persentase $55 \%$ dan luas lebih besar $>1$ ha sebanyak 9 orang dengan persentase $45 \%$.

\section{Pendapatan Petani Jagung}

Pendapatan ialah hasil yang di terima oleh seseorang setelah bekerja.

\begin{tabular}{|c|c|c|c|c|c|}
\hline No & $\begin{array}{l}\text { Jagung } \\
\text { Yang di } \\
\text { Tanam }\end{array}$ & Pendapatan & Pengeluaran & $\begin{array}{r}\text { Pendapatan } \\
\text { Bersih }\end{array}$ & $\begin{array}{r}\text { Rata- rata } \\
\text { Pendapatan } \\
\text { Bersih }\end{array}$ \\
\hline 1 & Jagung Manis & $2.350 .000,00$ & $640.000,00$ & $1.710 .000,00$ & $570.000,00$ \\
\hline \multirow{2}{*}{2} & Jagung Lokal & $39.730 .000,00$ & $13.150 .000,00$ & $26.580 .000,00$ & $1.563 .000,00$ \\
\hline & Jumlah & $42.080 .000,00$ & $13.790 .000,00$ & $28.290 .000,00$ & \\
\hline
\end{tabular}

Tabel 13 menunjukkan bahwa, pendapatan petani jagung manis sebanyak Rp. 2.350.000,00 dan biaya Pengeluaran Rp.640.000,00. Rata-rata pendapatan bersih dari 3 oarang petani jagung yaitu Rp. 570.000,00. Untuk pendapatan petani jagung lokal sebanyak Rp. 39.730.000,00 dengan biaya pengeluaran untuk pekerjaan sebanyak Rp. 13.150.000,00. Pendapatan bersih petani jagung lokal sebanyak Rp. 26. 580.000,00. Rata-rata pendapatan bersih petani jagung lokal yaitu dari 17 orang petani sebanyak Rp. 1.563.000,00.

\section{Sarana dan Pra-sarana}

Sarana dan prasarana adalah ketersediaan segala sesuatu yang di butuhkan untuk sebuah pekerjaan. Sarana dan prasarana yang dibutuhkan oleh kelompok tani ialah berupa benih, pupuk, alat dan tenaga kerja. Untuk masing-masing anggota kelompok tani mendapat sarana dan prasarana yang telah di fasilitasi oleh pemerintah lewat kelompok tani. Sehingga untuk semuanya lebih mudah didapat dan lebih mudah digunakan untuk penanaman jagung manis dan jagung lokal.

\section{Harga jual}

Harga jual menentukan pendapatan seseorang. Harga jual dari masing-masing anggota kelompok tani berbeda-beda. Untuk jagung lokal harga jual di mulai dari Rp. 2.500 - Rp. 4500/kg. Sedangkan untuk jagung manis dijual dengan harga Rp. 2500/tongkol.

\section{Rekapitulasi/Rangkuman Faktor-Faktor Yang Mempengaruhi Keputusan Petani Menanam Jagung Manis dan Jagung Lokal}

\section{Faktor Sosial}

Faktor sosial dalam penelitian ini ialah umur, tingkat pendidikan, pengalaman berusaha tani jagung, peran penyuluh pertanian. Umur terbagi atas umur non-produktif yakni $<15$ tahun +65 tahun ke atas, sedangkan umur produktif yakni 16- 64 tahun. Tingkat pendidikan responden terbagi atas tingkat SD, SMP dan SMA. Pengalaman berusaha tani jagung, yaitu berpengalaman dan belum berpengalaman. Peran penyuluh pertanian terhadap petani memberikan pengetahuan tentang jagung manis dan jagung lokal sehingga penyuluhan tentang jagung manis dan jagung lokal sama-sama berperan. 


\begin{tabular}{|c|c|c|c|c|c|c|c|}
\hline \multicolumn{8}{|c|}{ Tabel14. Faktor Sosial } \\
\hline \multirow[t]{2}{*}{ No } & \multirow[t]{2}{*}{ Falitor Sosial. } & & \multicolumn{2}{|c|}{ Jagung Manis } & \multicolumn{2}{|c|}{ Jagung Lokal } & \multirow[t]{2}{*}{ Keterangan } \\
\hline & & & Jumlah & Persentase $(\%)$ & Jumlah & Persentiase $\left(y_{0}\right)$ & \\
\hline \multirow[t]{3}{*}{1} & Umur & Produstif & 3 & 15 & 15 & 75 & jagung lokal lebih \\
\hline & & Non Produltifif & & & 2 & 10 & dominan \\
\hline & Tingkat & & & & & & \\
\hline \multirow[t]{4}{*}{2} & Pendiditan & SD & 2 & 10 & 5 & 25 & \multirow{4}{*}{$\begin{array}{l}\text { jagung lokal lebih } \\
\text { dominan }\end{array}$} \\
\hline & & SWP & & & 7 & 35 & \\
\hline & & SVA & 1 & 5 & 4 & 20 & \\
\hline & & D3SI & & & 1 & 5 & \\
\hline \multirow[t]{3}{*}{3} & \multicolumn{7}{|c|}{ Pengalaman berushaha Tari Jaguag } \\
\hline & Beppengalam & & 3 & 15 & 17 & 85 & jagung lokal lebih \\
\hline & Belum Berpe: & & & & & & dominan \\
\hline 4 & Peran Peanyl & eftarizan & & & & & Sama-sama bemeran \\
\hline
\end{tabular}

Tabel 14 menunjukkan, umur responden paling dominan ialah umur produktif petani jagung lokal sebanyak 15 orang dengan persentase $75 \%$.

Tingkat pendidikan petani jagung terbanyak ialah SMP sebanyak 7 orang dengan persentase $35 \%$ yaitu petani jagung lokal. Sedangkan tingkat pendidikan petani jagung lokal tingkat SD terdapat 5 orang dengan persentase $25 \%$, tingkat pendidikan petani jagung lokal tingkat SMA terdapat 4 orang dengan persentase $20 \%$ dan tingkat pendidikan D3/S1 terdapat 1 orang dengan persentase $5 \%$. Tingkat pendidikan petani jagung manis untuk tingkat SD sebanyak 2 orang dengan persentase $10 \%$ dan tingkat pendidikan petani jenjang SMA terdapat 1 orang dengan persentase $5 \%$.

Pengalaman berusaha tani jagung anggota kelompok tani Nafiri Jaya seluruhnya berpengalaman, baik petani jagung lokal maupun jagung manis. Peran penyuluh pertanian dalam memberikan penyuluhan tentang tanaman jagung sama-sama berperan dalam memajukan kelompok Tani Nafiri Jaya.

Untuk faktor sosial, umur menjelaskan bahwa jagung lokal lebih dominan. Untuk umur produktif maupun non produktif jagung lokal lebih dominan. Begitu juga dengan tingkat pendidikan, pengalaman berusaha tani jagung yang berpengalaman maupun belum berpengalaman, jagung lokal lebih dominan sedangkan untuk peran penyuluh pertanian jagung lokal dan jagung manis sama-sama berperan.

\section{Faktor Ekonomi}

Faktor ekonomi dalam penelitian ini ialah jumlah tanggungan dalam keluarga, luas lahan, sarana dan prasarana, pendapatan, pengeluaran dan harga jual.

Jumlah tanggungan dalam keluarga terdiri dari responden dengan tidak ada tanggungan, responden dengan tanggungan 1-2 orang dan responden dengan tanggungan diatas 3 orang. Luas lahan responden terbagi atas lahan dengan luas $<1$ ha dan lahan dengan luas >1ha. Sarana dan prasarana yang di butuhkan responden ialah benih, pupuk, alat dan tenaga kerja. Pendapatan responden atau petani tergantung jenis jagung yang ditanam. Biaya pengeluaran dari responden untuk penanaman jagung manis dan jagung lokal berupa biaya penanaman, pemeliharaan/pupuk, pemberantasan hama dan penyakit, biaya pasca panen dan biaya pemasaran. Harga jual untuk jagung manis dan jagug lokal tergantung harga pasar.

\begin{tabular}{|c|c|c|c|c|c|c|}
\hline \\
\hline \multirow[t]{2}{*}{$\bar{S}_{0}$} & \multirow[t]{2}{*}{ Filatu Elononi } & \multicolumn{2}{|c|}{ 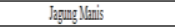 } & \multicolumn{2}{|c|}{ Jagngylahl } & \multirow[t]{2}{*}{ Etetergan } \\
\hline & & Julath & Persetsere $(4)$ & Julleth & Persentaste (10) & \\
\hline \multirow[t]{4}{*}{1} & 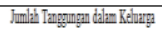 & & & & & \\
\hline & 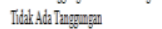 & 1 & 5 & & & \\
\hline & 1.20 rang & 1 & 5 & 6 & 30 & jegnglakal lethih doming \\
\hline & 30 magheatas & 1 & j & 11 & 55 & \\
\hline \multirow[t]{4}{*}{2} & Luas Lhan & & & & & \\
\hline & Weth heil $\leqslant$ the & 3 & 15 & 8 & 45 & \\
\hline & Wtith bess s the & & & 9 & 40 & jugng lotal lathin doring \\
\hline & Seread dan Praseden & & & & & \\
\hline \multirow{4}{*}{3} & Beih & & & & & 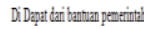 \\
\hline & Puple & & & & & 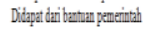 \\
\hline & Alat & & & & & Alatyand dignehn sma \\
\hline & Tengeg Reja & & & & & Tengeg keji: sma \\
\hline 4 & Peadpatan & & $\operatorname{Rp} 235000000$ & & Rp. $39.730 .000,0$ & 0 jegng hall tebih doring \\
\hline ; & Pengedurn & & Rp. 640.000000 & & Rp 131515000000 & 0 jognglobl leth dorim \\
\hline 6 & Hagry hal & & Rp2 2500 Inogalal & & 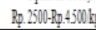 & g jogngmanis lethi mabl \\
\hline
\end{tabular}

Tabel 15 menunjukkan bahwa jumlah tanggungan dalam keluarga petani jagung lokal kebanyakan mendapat tanggungan 3 orang keatas sebanyak 11 orang dengan persentase $55 \%$. Sedangkan jumlah petani jagung manis yang tidak ada tanggungan, dengan tanggungan 1-2 orang dan tanggungan 3 orang keatas masing-masing 1 orang dengan persentase maseng-masing 5\%. Sedangkan petani jagung lokal dengan tanggungan 1-2 orang sebanyak 6 orang dengan persentase $30 \%$.

Sarana dan prasarana yang di butuhkan oleh petani jagung manis berupa benih di peroleh secara individu sedangkan untuk jagung lokal di peroleh dengan bantuan dari pemerintah. Untuk pupuk, alat yang di gunakan dan tenaga kerja semuanya sama.

Pendapatan per hektar usahatani jagung lokal lebih tinggi dibandingkan usahatani jagung manis. Untuk jagung lokal harga jual di mulai dari Rp. 2.500- Rp. 4500/kg. Sedangkan untuk jagung manis dijual dengan harga Rp. 2500/tongkol.

Keputusan petani untuk menggunakan benih jagung local dan jagungmanis dipengaruhi oleh faktor pendapatan usahatani. Artinya semakin tinggi tingkat pendapatan petani, akan semakin tinggi kecenderungan petani untuk memutuskan menggunakan benih jagung lokal. Selain itu, benih jagung lokal diperoleh dari pemerintah setempat melalui kelompok tani, sedangkan benih jagung manis sulit didapatkan karena harus dibeli secara individual.

Hasil produksinya, pendapatan petani jagung manis sebanyak Rp. 2.350.000,00 dan Pengeluaran Rp $640.000,00$. Untuk pendapatan petani jagung lokal sebanyak Rp. 39.730.000,00 dengan biaya pengeluaran untuk pekerjaan sebanyak Rp. 13.150.000,00. 
Untuk faktor ekonomi, jumlah tanggungan dalam keluarga yang ada tanggungan maupun tidak ada tanggungan jagung lokal lebih dominan. Begitu juga dengan luas lahan, jagung lokal lebih dominan. Sarana dan prasarana untuk benih dan pupuk didapatkan dari pemerintah, alat yang digunakan untuk jagung manis dan jagung lokal sama. Begitu juga untuk tenaga kerja sama. Pendapatan, dan pengeluaran jagung lokal lebih dominan. Dan untuk harga jual, jagung manis lebih mahal.

\section{KESIMPULAN DAN SARAN}

\section{Kesimpulan}

Berdasarkan penelitian ini, faktor-faktor yang mempengaruhi keputusan petani menanam jagung manis dan jagung lokal terdiri dari faktor sosial dan faktor ekonomi. Faktor sosial terbagi atas umur, tingkat pendidikan, pengalaman berusaha tani jagung dan peran penyuluh pertanian. Faktor ekonomi terbagi atas jumlah tanggungan dalam keluarga, luas lahan, sarana dan prasarana, pendapatan, pengeluaran dan harga jual.

\section{Saran}

1. Bagi Petani, diharapkan dalam mengambil keputusan menggunakan jenis benih yang lebih menguntungkan yang akan digunakan untuk penanaman.

2. Bagi anggota kelompok tani diharapkan bisa lebih giat lagi dalam mengadakan pertemuan.

\section{DAFTAR PUSTAKA}

Hanson, S. O. 2005. "Decision Theory, A Brief Introduction" Diakses tanggal 3 April 2019.Google Scholar.

Hasyim, Hasman. 2006. Analisis Hubungan Karakteristik Petani Kopi Terhadap Pendapatan (Studi Kasus: Desa Dolok Seribu Kecamatan Paguran Kabupaten Tapanuli Utara). Jurnal Komunikasi Penelitian. Lembaga Penelitian. Universitas Sumatera Utara, Medan.

Kementerian Perindustrian, 2018 Tentang Kebutuhan Jagung Nasional.
Koswara.2009. Respons Pertumbuhan Dan Produksi Tanaman Jagung Manis (Zea mays saccharata Sturt) Terhadap Pemberian Pupuk Cair Tnf Dan Pupuk Kandang Ayam. Balai Penelitian Tanah.

Purwono dan Hartono, 2007. Bertanam Jagung Unggul. Penebar Swadaya. Bogor.

Rogers, Everett M. 2003.Diffusion of Innovation.New York : The Free Press.Diakses tanggal 3 April 2019.Google Scholar.

Rukmana,Rahmat.2008. Bayam, Bertanam dan Pengolahan Pascapanen. Yogyakarta: Kanisius.

Sahidu, Arifuddin. 1998. Partisipasi Masyarakat Tani Pengguna Lahan sawah dalam Pembanguan Pertanian di Daerah Lombok, Nusa Tenggara Barat. [Disertasi] Institut Pertanian Bogor. Bogor.

Sajogyo dan Pudjiwati Sajogyo. 1999. Sosiologi Pedesaan. Yogyakarta : Gadjah Mada University Press.

Schiffman dan Kanuk. 2004. Perilaku Konsumen.Edisi 7. Prentice Hall. Jakarta.

Senoaji, G.,2011, Kondisi Sosial Ekonomi Masyarakat Sekitar Hutan Lindung Bukit Daun di Bengkulu.

Soekartawi.2003. Prinsip Dasar Manajemen Pemasaran Hasil Pertanian Teori dan Aplikasi. Rajawali Press. Jakarta.

Suharnan. 2005. Psikologi Kognitif. Surabaya. Srikandi.

Suratiyah, K. 2008. Ilmu Usahatani. Jakarta : Penebar Swadaya.

Syukur, M.dan A. Rifianto. 2014. Jagung Manis. Penebar Swadaya. Jakarta

Terry G. R. 2000.Prinsip-Prinsip Manajemen (edisi bahasa Indonesia), PT. Bumi Aksara, Bandung. 